
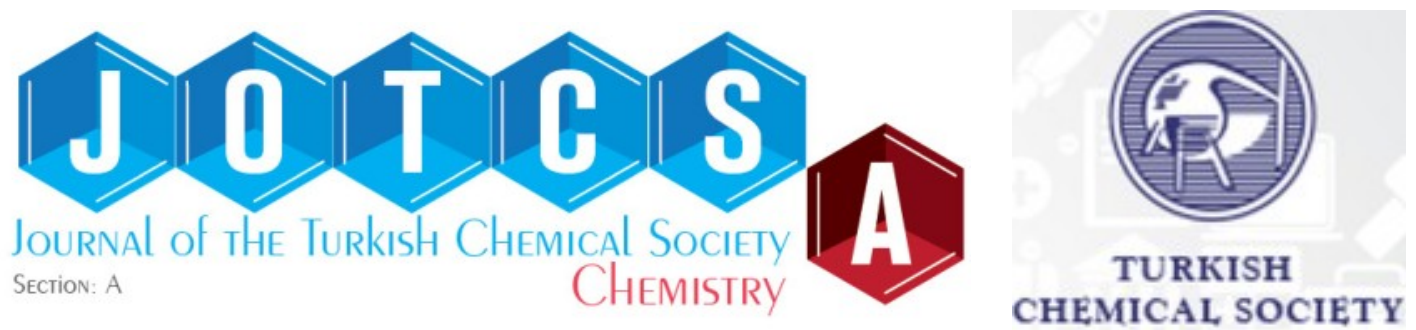

\title{
Evaluation of Changes in the Biological Activity of Onosma Sericeum Willd (Boraginaceae) Based on Collection Time and Extraction Solvent, and Determination of Its Mineral and Trace Element Composition
}

\author{
Selda Doğan Çalhan ${ }^{1 *}$, Mustafa Gündoğan ${ }^{2} \mathbb{Q}$ \\ ${ }^{1}$ Mersin University, Faculty of Pharmacy, Department of Pharmaceutical Biotechnology, 33169 Mersin, \\ Turkey. \\ ${ }^{2}$ Mersin University, Faculty of Pharmacy, Department of Pharmaceutical Technology, 33169 Mersin, \\ Turkey.
}

Abstract: In this study, total phenol, flavonoid, and free radical scavenging activity of Onosma Sericeum Willd (Boraginaceae), a plant grown in Turkey and traditionally used for wound healing, were determined by using spectrophotometric methods. Its cytotoxic effect on breast cancer cells (MCF-7) was investigated. Furthermore, mineral and trace element composition of the plant roots, collected in different times, was determined by using inductively coupled plasma mass spectroscopy (ICP-MS). Onosma Sericeum Willd, which was collected in Besni region, Adıyaman in May, June and July and dried properly, was extracted by using different solvents in the study. Total phenol content of the extracts was calculated by using the Folin-Ciocalteu method in gallic acid equivalent as $58.42 \pm 0.13-93.34 \pm 0.68 \mathrm{mg}$ $(\mathrm{GAE}) / \mathrm{g}$. The flavonoid content was calculated as $21.79 \pm 1.3-60.33 \pm 0.36 \mathrm{mg}(\mathrm{KUE}) / \mathrm{g}$ in quercetin equivalent by using the aluminum chloride method. Free radical scavenging activity was measured spectrophotometrically by using the 2,2-diphenyl-1- picrylhydrazyl (DPPH) assay. DPPH radical scavenging activity rates were found to be in the range of $60.27 \pm 0.06-78.60 \pm 0.21 \%$ in the form of $\%$ inhibition. It was observed that extracts which were prepared by using ethanol produced the cytotoxic effect on the MCF-7 cancer cells depending on the dosage. It was concluded that the rates of phenol, flavonoid, free radical scavenging activity, and cytotoxic effect differed based on the solvent used for extraction and the time of plant collection. Moreover, trace element and mineral composition of the plant samples, collected in different times, were determined.

Keywords: Boraginaceae, phenolic species, antioxidant activity, wound healing, element composition.

Submitted: July 01, 2019. Accepted: August 25, 2019.

Cite this: Doğan Çalhan S, Gündoğan M. Evaluation of Changes in the Biological Activity of Onosma Sericeum Willd (Boraginaceae) Based on Collection Time and Extraction Solvent, and Determination of Its Mineral and Trace Element Composition. JOTCSA. 2019;6(3):355-64.

DOI: https://doi.org/10.18596/jotcsa.585036.

*Corresponding author. E-mail: seldadgn@gmail.com.

\section{INTRODUCTION}

Mankind has sought ways of coping with diseases since the beginning of the world, and this adventure is still ongoing. One of the primary sources used by people in this process is plants. Archeological research indicates that herbal medicine dates back to the ancient times. Increased knowledge of plants over time and positive outcomes of the treatment of diseases brought along the concept of medication. Therefore, the first medications were herbal drugs. Considering the plant diversity and population worldwide, and the possibility of finding dozens of active substances with pharmaceutical efficacy in every plant, we come to realize how an endless world we live in. Hence, knowledge that has been acquired and learned for centuries has resulted in the cooperation of different disciplines in this area.

Turkey hosts a wide variety of plant species due to its geographical location and diverse climate. One of them is the family Boraginaceae. Spread in the tropical, subtropical and temperate regions of the world, the family is represented 
by 154 genus and 2500 species. The primary regions where the family shows greatest diversity are Iran-Turan and the Mediterranean. The family is also present in the Central and North America. Growing in different regions of Turkey, the family Boraginaceae includes 357 taxons, consisting of 34 genera, 325 species, 16 subspecies and 16 variants. Phytochemical analyses indicate that the family Boraginaceae, rich in naphthoquinone, includes alkanninshikonin and their derivatives (1). In pharmacological activity studies, it is acknowledged that these are strong candidates with pharmaceutical potential thanks to their antimicrobial, antifungal and anti-inflammatory activity as well as anticancer effects with the inhibition of topoisomerase I and topoisomerase II (2). The genus Onosma L. is the largest one in the family Boraginaceae $(3,4)$. The word Onosma derives from the Greek word "onos" and "osmê", and Latin word "osma". It means "scent, fragrance", and locally known as "emzik otu" or "yalancı hava civa" in Turkish.

Because of the considerable use of the Onosma species particularly in traditional medicine,

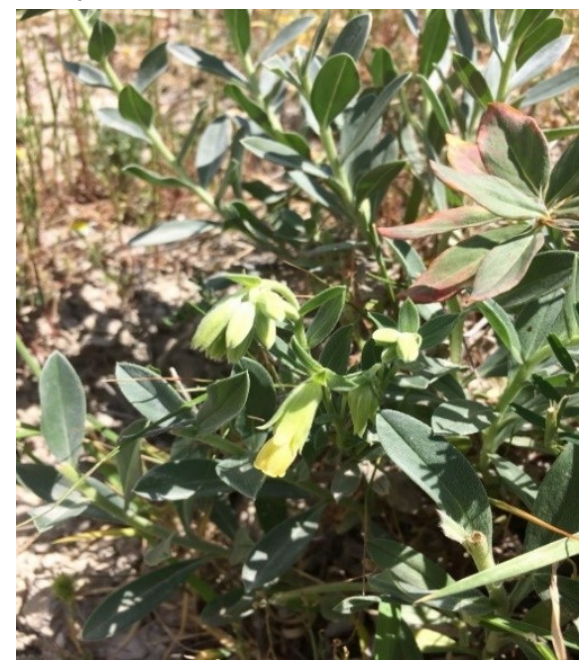

significant research has been conducted on them for many years. Traditional use of the Onosma species among local people in Turkey includes the treatment of bronchitis, tonsillitis and hemorrhoid (5). It was found that root extract of the Onosma argentatum comprises bioactive compounds with antioxidant and antimicrobial effects such as deoxyshikonin, acetylshikonin, 3hydroxy-isovalerylshikonin and 5,8-0-dimethyl acetylshikonin $(6,7)$. It was reported that Onosma echioides extract helps diminishing the growth of tumors and oxidative stress (8). Ozer et al. stated that Onosma heterophyllum (Griseb) has enzyme inhibitory and antioxidant activities (9).

It is well known that some species under the family Boraginaceae (Onosma Sericeum Willd., Onosma Microcarpum Steven ex D.C.) produce wound healing effects in traditional application, and are used for the treatment of burns (10). Onosma Sericeum Willd in particular is used in diverse areas such as food and textile thanks to the red pigments in its roots (11).

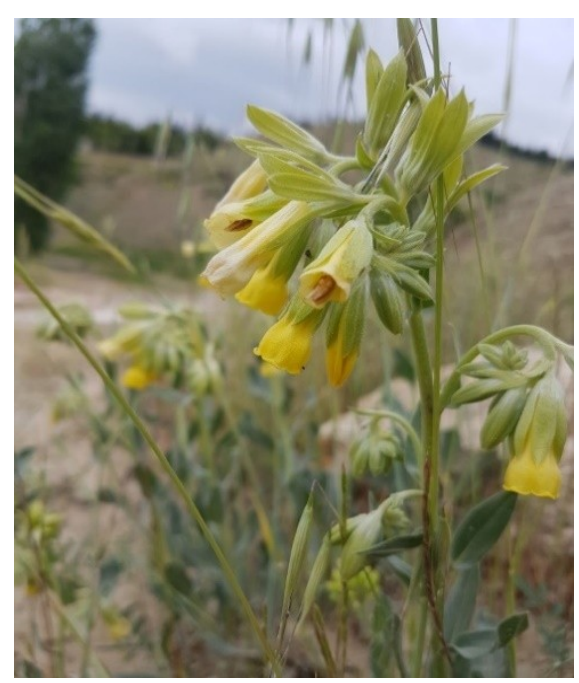

Figure 1. Onosma Sericeum Willd.

Onosma sericeum, the subject of this study, has been used to treat injuries and burns in Adıyaman for many years. It is known that mostly cream formulations, prepared with the roots of the plant, help treatment, without leaving scars. As is well-known, natural and/or synthetic molecules have been used for a long time for treatment in the process of healing injuries, in which many different variables are at play. Among them, especially plants and plant extracts attract a great deal of attention. Plants are frequently used in healing injuries due to their phenolic compounds and antioxidant properties in particular. It is known that polyphenols and antioxidants, considered as bioactive compounds, have antiinflammatory and anticarcinogenic effects (12). Another important point about plants is the time of collection, because the amount and composition of bioactive compounds may vary depending on the time they are collected. Another aim of this study was to explore the mineral and trace element composition of the Onosma Sericeum Willd, in addition to its biological activities, which has been the subject of few studies. Determining the mineral and trace element composition of the plant is vital for both identifying its positive effects on metabolic processes and human health, and for detecting potential toxic effects on plants with increasing environmental pollution. This is because element levels are affected by pesticide residues, industrial pollution and automobile exhaust to which the plant is exposed where its grows $(13,14)$.

In light of this information, the Onosma Sericeum Willd, a member of the family Boraginaceae, was collected in May, June and 
July, extracted by using different solvents, and total phenolic, flavonoid content and free radical scavenging activity of the extracts weredetermined. Cytotoxic effect of different extracts on the MCF-7 breast cancer cell was investigated. Trace element and mineral composition of the plant which was gathered in different times was also identified.

\section{MATERIALS AND METHODS}

\section{Collection and Identification of Plant Material}

Specimens of the Onosma Sericeum Willd (Boraginaceae) used in the study were gathered in Besni district of Adıyaman, Turkey in May, June and July 2018. The plant was identified by Assoc. Prof. Riza Binzet from the Department of Biology of the Faculty of Arts and Sciences, Mersin University. After properly dried, roots of the plant were used throughout the study.

\section{Materials}

Methanol and ethanol, used as extraction solvents in the study, were procured from Merck. Folin-Ciocalteu phenol reagent, 2-2diphenyl-1-picrylhydrazyl (DPPH), ascorbic acid, and gallic acid were obtained from Sigma. Sodium carbonate was procured from Tekkim. Quercetin, aluminum chloride (Fluka), sodium nitrite (Merck) and sodium hydroxide were supplied by Sigma. Nitric acid (65\%, Merck), hydrochloric acid (37\%, Merck), hydrogen peroxide (30\%, Merck), and dimethyl sulfoxide (99.9\%, Merck) were used in experimental work. Cell culture applications used fetal bovine serum (Sigma), Trypsin-EDTA solution (Sigma), Penicillin-Streptomycin solution (Sigma), Thiazolyl blue tetrazolium bromide (MTT) (98\%, Sigma) and RPMI 1640 medium (Sigma). The MCF-7 breast cancer cells were procured from ATTC (catalogue number: HTB-22). All the chemicals used in the study were of analytical grade, and $18.2 \mathrm{~m} \Omega$ of distilled water needed throughout the research was obtained through the Milli-Q A10 water purification system.

\section{Instruments}

All spectrophotometric measurements were conducted by using a Shimadzu UV-1601 spectrophotometer. Element and mineral composition was analyzed by using the Agilent 7500ce Inductively Coupled Plasma-Mass Spectrometry (ICP-MS). CEM Mars 240/50 microwave system was used to digest the samples on the ICP-MS. Thermal shaking water bath was used for plant extraction. The study also used Heidolph Reaxtop vortex and Heidolph Laborota 4000 efficient evaporator.

\section{Extraction Procedure}

$5 \mathrm{~g}$ of crushed plant roots was obtained, and mixed with $25 \mathrm{~mL}$ of ethanol (EtOH), methanol $(\mathrm{MeOH})$, and boiled water, respectively. It was kept in shaking water bath for 1 hour. This procedure was repeated 3 times. Later, the extracts were filtered withwhite filter paper and evaporated at maximum $40{ }^{\circ} \mathrm{C}$ by using a rotary evaporator. Dried extracts were dispersed by using solvents, and stock solutions were prepared and filtered through $0.45 \mu \mathrm{m}$ membrane filters. The stock solutions were stored under suitable conditions to be used in determining biological activity and trace element/mineral composition. Nine different extracts which were collected in May, June and July were named as May EtOH, May $\mathrm{MeOH}$, May water, June $\mathrm{EtOH}$, June $\mathrm{MeOH}$, June water, July $\mathrm{EtOH}$, July $\mathrm{MeOH}$ and July water.

\section{Total Phenolic Content Analysis}

Total phenolic content of the extracts was determined spectrophotometrically by using the Folin-Ciocalteu method (15). $100 \mu \mathrm{L}$ of sample/ extract sample was mixed with $7900 \mu$ Lof distilled water and $500 \mu \mathrm{L}$ of Folin-Ciocalteu's reagent in a test tube $(10 \%, \mathrm{v} / \mathrm{v}$ in water). The mixture was vortexed and allowed to stand to incubate in the dark at room temperature for 2 minutes. After that, $1.5 \mathrm{~mL}$ of $\mathrm{Na}_{2} \mathrm{CO}_{3}$ (20\%) solution ( $\mathrm{w} / \mathrm{v})$ was added to the mixture, and it was vortexed again. After the mixture was kept in the dark at room temperature for 2 hours, absorbance of the resulting blue solutions was measured by using the UV spectrophotometer at $765 \mathrm{~nm}$ wavelength. Gallic acid was used as standard. Results were expressed as average of the three measurements, in $\mathrm{mg} G A E / g$ dry weight.

\section{Total Flavonoid Content Analysis}

Total flavonoid content of the extracts was determined spectrophotometrically through the aluminum chloride/sodium nitrite method (16). After $500 \mu \mathrm{L}$ of extract sample, diluted to a certain extent, was placed in a test tube with 3 $\mathrm{mL}$ of distilled water, $0.3 \mathrm{~mL}$ of aqueous $\mathrm{NaNO}_{2}$ solution ( $5 \%$ ) was added, and the mixture was vortexed. After 5 minutes, $0.3 \mathrm{~mL}$ of aqueous $\mathrm{AlCl}_{3}$ solution (10\%) was added to the mixture. Then, by adding $2 \mathrm{~mL}$ of $1 \mathrm{M} \mathrm{NaOH}$ after 1 minute, the final volume of the mixture was completed to $10 \mathrm{~mL}$, with distilled water. This final mixture was vortexed again, and its absorbance was measured at $510 \mathrm{~nm}$. Results were expressed as the average of the three measurements, in mg Quercetin/g dry weight.

\section{DPPH'Free Radical Scavenging Activity}

Free radical scavenging activity of the extracts was assessed spectrophotometrically through the DPPH method (17). $100 \mu \mathrm{L}$ of the root extract and ascorbic acid solution with different concentrations, used as standard, was mixed with $2.9 \mathrm{~mL}$ of $80 \mu \mathrm{M}$ DPPH solution, freshly prepared in methanol. The mixture was vortexed and kept in the dark for 1 hour to incubate. After this procedure, absorbance of each mixture was measured at $517 \mathrm{~nm}$. Theresults are given as average of the three measurements, in \% inhibition (Equation 1). 


$$
\% \text { Inhibition }=\left[\left(\mathrm{Abs}_{\text {control }}-\mathrm{Abs}_{\text {sample }}\right) / \mathrm{Abs}_{\text {control }}\right] \times 100
$$

(Eq. 1)

\section{Cytotoxic Effect}

The MTT (3-(4,5-dimethylthiazolyl-2)-2,5diphenyltetrazolium bromide) assay, a colorimetric method, is based on the principle of the reduction of tetrazolium salt to colored formazans. Cell viability is assessed by dying the cells at various levels with the MTT according to their mitochondrial activity. After the formazan crystals are dissolved, reading is made at 570 $\mathrm{nm}$ wavelength. The present study used the method proposed by Turan et al. (18) with some modification. In the present study, the MCF-7 cells were seeded into 4 plates containing 96 wells, with $10^{4}$ cells in each well. Water was placed in the outermost wells of the plates to adjust moisture balance. Nine samples (May $\mathrm{EtOH}$, May $\mathrm{MeOH}$, May water, June $\mathrm{EtOH}$, June $\mathrm{MeOH}$, June water, July $\mathrm{EtOH}$, July $\mathrm{MeOH}$, July water) were administered to the MCF-7 breast cancer cells in 3 different concentrations $(50 \mu \mathrm{g} /$
$\mathrm{mL}, 100 \mu \mathrm{g} / \mathrm{mL}, 200 \mu \mathrm{g} / \mathrm{mL}$ ). The procedure was repeated 10 times for each concentration $(n=10)$. After 24 hours, the extracts in the cells were taken from the wells and mixed with the MTT solvent. The cells were kept for incubation at $37{ }^{\circ} \mathrm{C}$, with $5 \% \mathrm{CO}_{2}$. The plates were wrapped with aluminum foil to prevent the entrance of light. The cells were taken out after being kept in incubation for 5 hours, the medium over them was removed, and $200 \mu \mathrm{L}$ of dimethyl sulfoxide was added to each well. In this way, unsolved formazan crystals were also dissolved. After waiting for 15 minutes, they were measured by using an ELISA set at $570 \mathrm{~nm}$ wavelength. Outer wells which did not contain any cells were introduced as empty. IC50 value and cell viability was calculated by using the absorbance rates and the formula in Equation 2.

Relative cell viability (\%) $=$ OD570 of the treated sample/OD570 of the control (Eq. 2)

To count the viable cells, Cedex XS (Roche, Mannheim, Germany) was used. This device distinguishes between viable and non-viable cells with high precision, by providing information about cell concentration and viability based on the trypan blue exclusion method, in a semi-automatical manner. $20 \mu \mathrm{L}$ of resuspended cells were taken and added to $0.2 \mathrm{~mL}$ of Eppendorf tube. The cells were mixed with $20 \mu \mathrm{L}$ of trypan blue solution (0.4\%), diluted with distilled water which helps to distinguish between viable and non-viable cells (Roche, Mannheim, Germany). After this mixture was homogenized through pipetting, $20 \mu$ Lof it was put in the Smart Slides chamber, special slide of the device (Roche, Mannheim, Germany). Later, the sample was placed on the Cedex XS cell counter in the chamber, and the cells were counted by using the software of the device.

\section{Determination of Mineral and Trace Element Composition}

$0.5 \mathrm{~g}$ of the plant roots which were collected in May, June and July was obtained, and digested using the heat controlled microwave system. For this procedure, $12 \mathrm{~mL}$ of nitric acid-hydrochloric acid mixture and $1 \mathrm{~mL}$ of hydrogen peroxide were used. Digestion process took 30 minutes at $175^{\circ} \mathrm{C}$. The system settings of the device were optimized to 239 PSI and 720 w. After the resulting acidic solution was diluted properly, measurements were made through the ICP-MS. Operating parameters of the ICP-MS device are given in Table 1.

\section{Statistical Analysis}

The results were calculated by taking the average of the three measurements and standard deviation (mean \pm SD). Repeated Measures Analysis of Variant was used for comparing more than two dependent averages (in different times). Contrast process was used to determine in which time intervals the difference occurred. The statistical significance level was set at 0.05 in all analyses. The data was analyzed by using SPSS 21 .

Table 1. Operating Conditions of ICP MS.

\begin{tabular}{ll}
\hline Parameter & Value \\
\hline RF power & $1500 \mathrm{~W}$ \\
Sampling Depth & $8.8 \mathrm{~mm}$ \\
Flow Rates of Plasma Gas & $15 \mathrm{~L} / \mathrm{min}$ \\
Flow Rates of Carrier Gas & $0.9 \mathrm{~L} / \mathrm{min}$ \\
Flow Rates of Auxiliary Gas & $1 \mathrm{~L} / \mathrm{min}$ \\
Integration Time & $0.60 \mathrm{~s}$ \\
\hline
\end{tabular}

\section{RESULTS AND DISCUSSION}

It is known that the genus Onosma, including the Onosma Sericeum Willd, the subject of thepresent study, is used in traditional treatment, especially in healing wounds (19, 20). Studies conducted on the Onosma roots found alkannin/ shikonin derivatives displaying biological activity and these structures have healing, anti-inflammatory, anti-tumor, antithrombotic, and anti-microbial properties (2123). For this reason, it is highly important and necessary to carry out biological activity research on this genus. Thus, this study investigated the biological activity of theOnosma Sericeum Willd species, which is not studied as much as the other Onosma species, depending on collection time and extraction solvent. The study also determined its element composition which plays significant roles and/or has toxic effects in biological processes.

In the study, Onosma Sericeum Willd was collected in Besni region, Adıyaman in May, June 
and July 2018, and its roots were extracted by using ethanol, methanol, and water. The total phenol, flavonoid content and DPPH radical scavenging activity of the extracts were determined. The cytotoxic effect of the extracts on the MCF-7 cells was investigated through the MTT method. Trace element and mineral composition of the plant samples, collected in different periods, was determined through the ICP-MS after the samples were digested using microwave.

Total phenol was determined by Folin-Ciocalteu reactive using the spectrophotometric method. A calibration graphic was created by preparing gallic acid solutions in specific concentrations (used as standard)and the amount of sample in the extract was calculated in gallic acid equivalent as $58.42 \pm 0.13-93.34 \pm 0.68 \mathrm{mg}(\mathrm{GAE}) /$ $\mathrm{g}$ by taking into consideration $y=0.001 x+0.0033, \quad R^{2}=0.9901 \quad$ regression equation and dilution.
The total flavonoid content was determined through the spectrophotometric method by using the aluminum chloride/sodium nitrite method. A calibration graphic was created by preparing quercetin solutions in specific concentrations (used as standard), and the amount of sample in the extract was calculated in quercetin equivalent as $21.79 \pm 1.3-60.33 \pm 0.36 \mathrm{mg}(\mathrm{KUE}) /$ $\mathrm{g}$ by taking into consideration $y=0.0002 x+0.0078, \quad R^{2}=0.9717 \quad$ regression equation and dilution.

The DPPH radical scavenging activity rates of the extracts were given in $\%$ inhibition which is used as the indicator of antioxidant activity. Calculations were carried out based on $y=-$ $0.0038 x+0.7616$ regression equation and Equation 1. According to the results, it was found that the \% inhibition rates were in the range of $60.27 \pm 0.06-78.60 \pm 0.21 \%$.

All the results are given as the average of the three measurements and with standard deviation rates (Table 2 ).

Tablo 2.Total phenol, flavonoid, and \% inhibition rates of the Onosma Sericeum Willd extract.

\begin{tabular}{llll}
\hline & $\begin{array}{l}\text { PHENOL CONTENT* } \\
\text { mg GAE/g }\end{array}$ & $\begin{array}{l}\text { FLAVONOID } \\
\text { CONTENT } \\
\text { KUE/g }\end{array}$ & $\begin{array}{l}\text { RADICAL } \\
\text { ACTIVITY*\% Inhibition }\end{array}$ \\
\hline May EtOH & $93.34 \pm 0.68$ & $60.33 \pm 0.36$ & $60.27 \pm 0.06$ \\
May MeOH & $70.46 \pm 1.31$ & $46.79 \pm 0.95$ & $62.13 \pm 0.21$ \\
May Water & $62.36 \pm 0.13$ & $24.5 \pm 1.65$ & $78.60 \pm 0.22$ \\
June EtOH & $75.01 \pm 1.31$ & $40.54 \pm 0.95$ & $67.37 \pm 0.11$ \\
June MeOH & $68.19 \pm 1.31$ & $32.21 \pm 0.95$ & $61.09 \pm 0.27$ \\
June & $60.46 \pm 0.13$ & $23.25 \pm 1.25$ & $73.82 \pm 0.22$ \\
Water & & & \\
July EtOH & $70.08 \pm 0.47$ & $42.42 \pm 0.95$ & $66.87 \pm 0.38$ \\
July MeOH & $59.78 \pm 0.26$ & $31.58 \pm 1.30$ & $60.81 \pm 0.23$ \\
July Water & $58.42 \pm 0.13$ & $21.79 \pm 1.30$ & $73.75 \pm 0.62$ \\
\hline
\end{tabular}

* The results were given based on dry weight and as the average of three measurements.

An assessment of the results indicated that the rates of phenol, flavonoid, and free radical scavenging activity differed according to collection time and extraction solvent, and the difference between the averages was statistically significant. A statistically significant difference was found in the phenol content between May EtOH, June EtOH, and July EtOH $(p=0.001)$. Accordingly, it was determined that the difference was between May and June $(p=0.001)$, May and July $(p=0.001)$, and June and July $(p=0.036)$ periods. It was observed that there was a statistically significant difference $(p=0.011)$ in the phenol content between $\mathrm{May} \mathrm{MeOH}$, June $\mathrm{MeOH}$, and July $\mathrm{MeOH}$ $(p=0.011)$; and this difference was between May and July $(p=0.004)$, and June and July $(p=0.007)$ periods. A statistically significant difference $(p<0.001)$ was also observed in the phenol content between May Water, June Water, and July Water. It was concluded that this difference $(p=0.002)$ was between May and July $(p<0.001)$, and June and July $(p<0.001)$ periods. Moreover,a statistically significant difference $(p<0.001)$ was identified in the flavonoid content between May $\mathrm{EtOH}$, June $\mathrm{EtOH}$, and July EtOH, which was found to be between May and June $(p=0.001)$ and May and July $(p=0.001)$. There was a statistically significant difference in the flavonoid content between $\mathrm{May} \mathrm{MeOH}$, June $\mathrm{MeOH}$, and July $\mathrm{MeOH}$ $(p=0.004)$. The difference was observed between May and June $(p=0.003)$ and May and July $(p=0.006)$ periods. The difference in the flavonoid content between May Water, June Water, and July Water $(p=0.011)$ was also statistically significant. Accordingly, this difference was between May and July $(p=0.006)$, and June and July $(p=0.020)$ periods. Another statistically significant difference was identified in the radical scavenging activity rates between May EtOH, June EtOH, and July EtOH $(p<0.001)$. The difference was between May and June $(p=0.001)$ and May and July $(p<0.001)$ periods. There was a statistically significant difference $(p=0.009)$ in the radical scavenging activity rates between $\mathrm{May} \mathrm{MeOH}$, June $\mathrm{MeOH}$, and July $\mathrm{MeOH}$. The difference was between May and 
June $(p=0.015)$ and May and July $(p=0.001)$ periods. Finally, a statistically significant difference was found in the radical scavenging activity rates between May Water, June Water, and July Water $(p=0.002)$, which was between May and July $(p<0.001)$ periods.

In a study by Mazandarani et al. (24) in 2011, phenolic and flavonoid contents were detected in different extraction solvents of the Onosma Dichroanthum Boiss (ethanol, methanol, acetone). According to the results of this study, the total phenol concentration varied between $4.5 \pm 0.7$ and $125.6 \pm 3.01 \mathrm{mgGAE} / \mathrm{g}$, and flavonoid concentration was between $9.8 \pm 3$ and $41 \pm 2.3 \mathrm{mgKUE} / \mathrm{g}$, which is compatible with the results of the present study.

In a biological activity study conducted as result of the extraction of theOnosmatauricum with ethyl acetate, methanol and water, the phenolic and flavonoid concentrations were determined as $40.88 \mu \mathrm{molGAEs} / \mathrm{g}$ and $7.40 \mu \mathrm{molREs} / \mathrm{g}$, respectively. This finding is also compatible with the results of the present study (25). The cytotoxic effect of the samples which were collected in May, June, and July and extracted by using ethanol, methanol, and water, respectively, on the MCF-7 cells was investigated through the MTT test (3-(4,5-dimethylthiazol-2yl)-2,5 -diphenyltetrazolium bromide), a colorimetric method. 24 hours after adding the extract, the \% relative cell viability of the MCF-7 cells was determined by using the Equation 2 . It was found that the extracts prepared with methanol and water did not have any cytotoxic effect on the cancer cells; on the contrary, these samples triggered the growth of these cells (Relative cell viability $>100$ ). In addition, it was found there was a significant cytotoxic effect, depending on the dosage, on the samples collected in May, June, and July and extracted with ethanol (Figure 2-4). Cell viability decreased in all concentrations compared to the control group. The concentration which decreased the cell viability most was $50 \mu \mathrm{g} / \mathrm{mL}$. The more the concentration increased, the more the cytotoxic effect on the cancer cells decreased. It is considered that the plant has a positive impact on cell growth due to its wound healing property, and it produced cytotoxic effect on the cancer cells in low concentrations while it affected the growth of cancer cells positively in high concentrations.

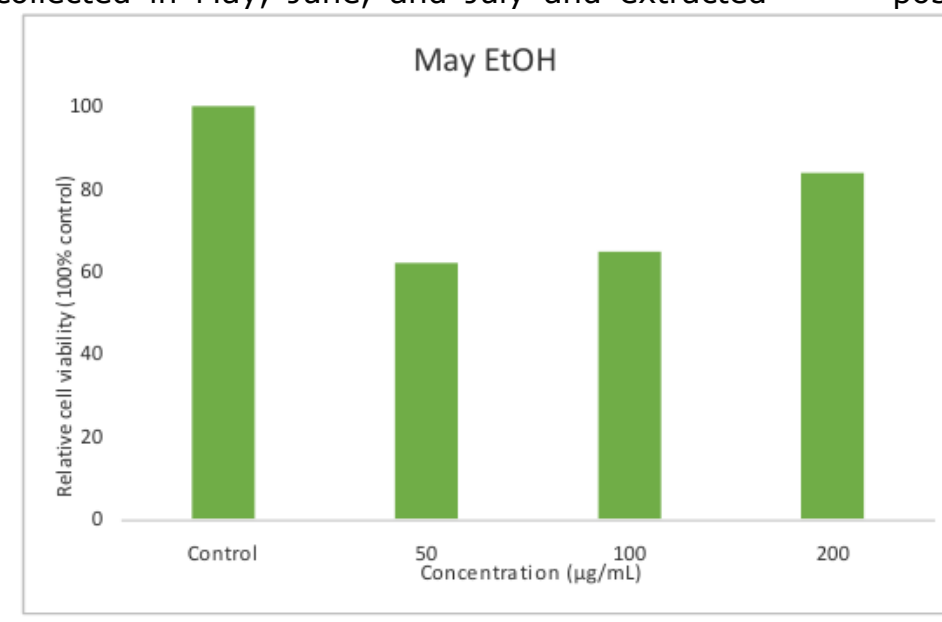

\begin{tabular}{cc}
\hline Conc $\mu \mathrm{g} / \mathrm{mL}$ & $\begin{array}{c}\text { Relative cell } \\
\text { viability }(\%)\end{array}$ \\
\hline May EtOH 50 & $62.13 \pm 11.33$ \\
May EtOH 100 & $64.58 \pm 12.39$ \\
May EtOH 200 & $83.79 \pm 11.83$ \\
\hline
\end{tabular}

Figure 2. Cell viability (\%) for May EtOH $50 \mu \mathrm{g} / \mathrm{mL}, 100 \mu \mathrm{g} / \mathrm{mL}$, and $200 \mu \mathrm{g} / \mathrm{mL}$.

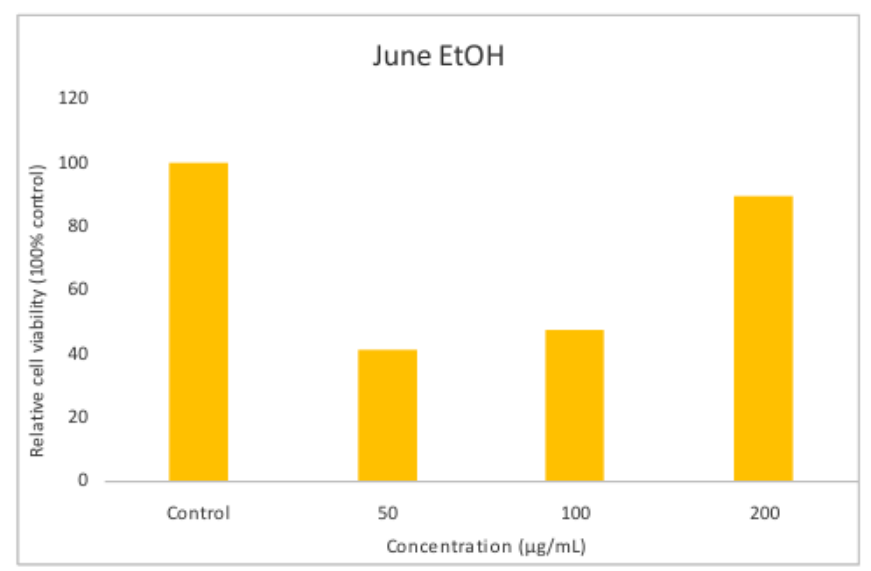

\begin{tabular}{ll}
\hline Conc $\mu \mathrm{g} / \mathrm{mL}$ & $\begin{array}{l}\text { Relative cell } \\
\text { viability }(\%)\end{array}$ \\
\hline June EtOH 50 & $40.92 \pm 6.81$ \\
June EtOH 100 & $47.47 \pm 15.3$ \\
June EtOH 200 & $89.55 \pm 20.77$ \\
\hline
\end{tabular}

Figure 3. Cell viability (\%) for June EtOH $50 \mu \mathrm{g} / \mathrm{mL}, 100 \mu \mathrm{g} / \mathrm{mL}$, and $200 \mu \mathrm{g} / \mathrm{mL}$. 


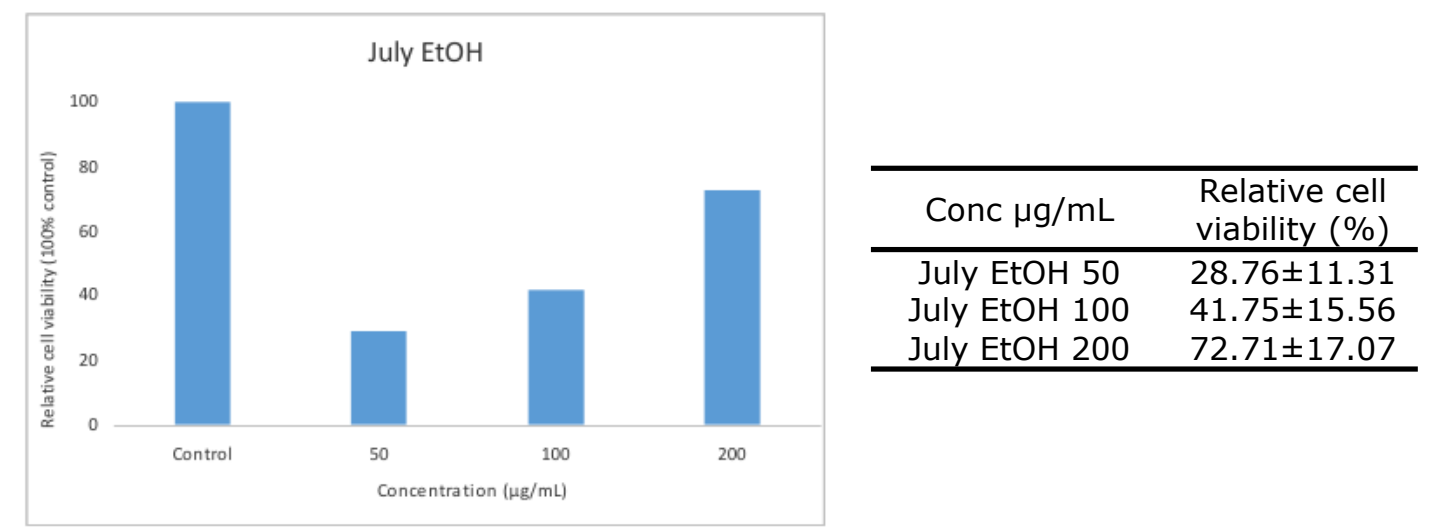

Figure 4. Cell viability (\%) for July EtOH $50 \mu \mathrm{g} / \mathrm{mL}, 100 \mu \mathrm{g} / \mathrm{mL}$, and $200 \mu \mathrm{g} / \mathrm{mL}$.

In a study investigating the cytotoxic effects of the Alkanna, another significant species in the family Boraganicae (26), five different cancer cell lines were used. Also using the MCF-7 cancer cells, the study assessed cytotoxic effects through the MTT analysis. Some of the findings demonstrated that the more the extract concentration decreased, the more cytotoxic effect increased. The study emphasized that the more the purity of biologically active substances creating cytotoxic effect increased, the more the amount of concentration, in which it was active, decreased. These results are consistent with the rates obtained in the present study. Moreover, the study reported that roots of the plant displayed higher cytotoxic effect than ground surface parts.

The present study revealed that the extract producing cytotoxic effect on the cancer cells was prepared in ethanol for all months. It was determined whether the dosage made any statistical difference for all months. A statistically significant difference was identified between May EtOH $50 \mu \mathrm{g} / \mathrm{mL}$, June EtOH $50 \mu \mathrm{g} /$ $\mathrm{mL}$, and July EtOH $50 \mu \mathrm{g} / \mathrm{mL}(p<0.001)$. This difference was between May and June $(p<0.001)$, May and July $(p<0.001)$, and June and July $(p<0.001)$ periods. The difference between May EtOH $100 \mu \mathrm{g} / \mathrm{mL}$, June EtOH 100 $\mu \mathrm{g} / \mathrm{mL}$, and July EtOH $100 \mu \mathrm{g} / \mathrm{mL}$ was statistically significant $(p=0.001)$. Accordingly, the difference was between May and June $(p=0.003)$ and May and July $(p=0.001)$ periods. However, there was no statistically significant difference between May EtOH $200 \mu \mathrm{g} / \mathrm{mL}$, June $\mathrm{EtOH} 200 \mu \mathrm{g} / \mathrm{mL}$, and July EtOH $200 \mu \mathrm{g} / \mathrm{mL}$ $(p=0.565)$.

After the Onosma Sericeum Willd, collected in May, June and July, was digested using the microwave, its trace element and mineral composition was defined. The results are given as the average of three measurements (Table 3).

Table 3. Total content of metals (ppb) in dried Onosma Sericeum Willd.

\begin{tabular}{|l|l|l|l|}
\hline & May & June & July \\
\hline $\mathrm{B}$ & $9944 \pm 1.594$ & $16328 \pm 4.598$ & $2262.4 \pm 3.196$ \\
\hline $\mathrm{Na}$ & $9600 \pm 0.002$ & $9600 \pm 0.003$ & $13600 \pm 0.012$ \\
\hline $\mathrm{Mg}$ & $47200 \pm 0.013$ & $67200 \pm 0.019$ & $7200 \pm 0.046$ \\
\hline $\mathrm{Al}$ & $4217.6 \pm 0.818$ & $5449.6 \pm 1.834$ & $9056 \pm 6.908$ \\
\hline $\mathrm{P}$ & $42040 \pm 9.444$ & $78200 \pm 2.244$ & $41288 \pm 2.255$ \\
\hline $\mathrm{K}$ & $909600 \pm 0.191$ & $1267200 \pm 0.240$ & $912000 \pm 0.540$ \\
\hline $\mathrm{Ca}$ & $508000 \pm 0.043$ & $939200 \pm 0.151$ & $1233600 \pm 0.748$ \\
\hline $\mathrm{Cr}$ & $1114.4 \pm 0.271$ & $1504.8 \pm 0.623$ & $1695.2 \pm 1.516$ \\
\hline $\mathrm{Mn}$ & $2238.4 \pm 0.309$ & $4124 \pm 0.965$ & $2818.4 \pm 1.659$ \\
\hline $\mathrm{Fe}$ & $12000 \pm 0.001$ & $13600 \pm 0.004$ & $15200 \pm 0.013$ \\
\hline $\mathrm{Co}$ & nd & nd & nd \\
\hline $\mathrm{Ni}$ & $234.4 \pm 0.037$ & $357.6 \pm 0.023$ & $339.2 \pm 0.157$ \\
\hline $\mathrm{Cu}$ & $1388 \pm 0.057$ & $1807.2 \pm 0.135$ & $1915.2 \pm 0.814$ \\
\hline $\mathrm{Zn}$ & $3107.2 \pm 0.037$ & $2702.4 \pm 0.085$ & $5067.2 \pm 2.124$ \\
\hline $\mathrm{As}$ & $395.2 \pm 0.105$ & $356 \pm 0.132$ & $362.4 \pm 0.322$ \\
\hline $\mathrm{Se}$ & $661.6 \pm 0.407$ & $278.4 \pm 0.162$ & $195.2 \pm 0.239$ \\
\hline $\mathrm{Cd}$ & $\mathrm{nd}$ & nd & nd \\
\hline $\mathrm{Sn}$ & $1549.6 \pm 0.200$ & $1887.2 \pm 0.043$ & $1600 \pm 0.861$ \\
\hline $\mathrm{Ba}$ & $4338.4 \pm 0.323$ & $10680 \pm 1.738$ & $11392 \pm 5.653$ \\
\hline $\mathrm{Pb}$ & nd & nd & nd \\
\hline $\mathrm{nd}$ & $\mathrm{nd}$ & & \\
\hline
\end{tabular}

nd: not detected 
As it is seen in Table 3, the concentration values of toxic elements such as cobalt, cadmium and lead could not be determined as they were below 1ppb. Nickel, arsenic, and selenium were relatively in low concentrations, and they were at proximate levels in three periods when the plant was collected. Among the toxic elements, only the concentration rate of aluminum was higher compared to nickel, arsenic and selenium. It was identified that all the other elements were essential and had higher concentration rates than other toxic elements.

\section{CONCLUSION}

The use of plants for therapeutic purposes is as old as the human history. In fact, mostly plant and plant extracts were used for medical purposes until the discovery of synthetic drugs. In this process until the present day, the idea that synthetic drugs have greater potential harmful effects has led people to use drugs of natural origin. Interest in natural products has increased gradually with the promotion of print and visual media. One of the significant disadvantages of this deep interest is the idea that natural products have no harmful or side effects. However, it is vital that herbal products are procured from reliable sources using proper methods, and recommended and administered by competent persons. Otherwise, it might result in serious mortality and morbidity. Besides, the data on plants, particularly those with traditional use, must be built on a scientific foundation. In addition to all these, the area where the plant grows, collection time, soil and climate conditions might change the quantity of bioactive components and composition of the plant. Moreover, it is necessary to carry out toxicity studies while determining the dosage to be used.It is a fact that antioxidant activity which plays a significant role especially in healing the wounds depends on the quantity of phenolic and flavonoid species. Thus, the present study investigated the changes in the biological activity of the Onosma Sericeum Willd, traditionally used and known for its therapeutic properties among public, depending on collection time and extraction solvent. Its cytotoxic effect on the MCF-7 was also investigated. The highest cytotoxic effect was detected in the extracts containing ethanol which also had high phenolic, flavonoid and radical scavenging activity rates. At the same time, the study assessed trace element/mineral composition which plays a significant role in understanding biological processes. The results demonstrated that biological activity changed depending on collection time and extraction solvent. Although the family Boraginacea has drawn the attention of many researchers due to its bioactive species, studies on the Onosma Sericeum Will, a member of this family, are considerably limited. In this sense, we believe that our study will make a contribution to the relevant literature. In continuation of this study, the researchers intend to carry out the isolation of bioactive compounds belonging to this species, assessment of their biological activities, and assessment of possible cytotoxic effects on different cells.

\section{ACKNOWLEDGEMENTS}

The authors thank Assoc. Prof. Dr. Rıza Binzet from the Department of Biology at the Faculty of Arts and Sciences, Mersin University for the botanical identification of the plant. We also thank the Department of Biostatistics and Medical Informatics, Faculty of Medicine, Mersin University and Specialist Asena Ayça Özdemir for their contributions in performing statistical analyses.

\section{REFERENCES}

1. Vukic MD, Vukovic NL, Djelic GT, Popovic S, Zaric MM, Baskic DD, Krstic GB, Tesevic VV, Kacaniova MM. Antibacterial and cytotoxic activities of naphthoquinone pigments from Onosma Visianii Clem. EXCLI Journal. 2017; 16:73-88.

2. Ozgen $U$, Ikbal $M$, Hacimuftuoglu $A$, Houghton P.J, Gocer F, Dogan H, Coskun M. Fibroblast growth stimulation by extracts and compounds of Onosma argentatum roots. J Ethnopharmacol. 2006;104:100-3.

3. Binzet R,Orcan N. A New species of Onosma (Boraginaceae) from Southern Turkey. Missouri Botanical Garden Press.2007;17(1): 8-10.

4. Akçin ÖE, Aktaş T, Altıntaş MY. Myosotis Alpestris F.W.Schmidt (Boraginaceae) türünün anatomik özellikleri. Ordu Univ. J. Sci. Tech. 2013;3(1): 61-8.

5. Tosun A, Akkol EK, Bahadır Ö, Yesilada E. Evaluation of anti-inflammatory and antinociceptive activities of some Onosma L. Species growing in Turkey.J Ethnopharmacol.2008;120:378-81.

6. Ozgen U, Coskun, M, Kazaz, C, Secen, H. Naphthoquinones from the roots of Onosma argentatumHub.-Mor (Boraginaceae). Turk J Chem. 2004;28: 451-4.

7. Ozgen U, Houghton, PJ, Ogundipe, Y, Coskun, $M$. The Antioxidant and antimicrobial activities of Onosma argentatum and Rubiaperegrina. Fitoterapia. 2003; 74: 682-5.

8. Sharma S,Khan, K, Sultana, S. Effect of Onosma echiodes on DMBA/croton oil mediated carvcinogenic response, hyperproliferation and oxidative damage in murine skin. Life Sci. 2004;75(20): 2391-410. 
9. Ozer MS, Kirkan B, Sarikurkcu C, Cengiz M, Ceylan O, Atılgan N, Tepe B. Onosmaheterophyllum:Phenolic composition, enzyme inhibitory and antioxidant activities. Ind Crops Prod. 2018;111:179-84.

10. Sezik E, Yeşilada E, Tabata M, Honda G, Takaishi Y, Fujita T, Tanaka T, Takedau Y. Traditional medicine in Turkey VIII. Folk medicine in East Anatolia; Erzurum, Erzincan, Ağrı, Kars, Igdır Provinces. Econ. Bot. 1997;51(3):195-211.

11. Gharehmatrossian S, Popov Y, Ghorbanli M, Safaeian S, Iranbakhsh A. Phytochemical and morphological evidences for Shikonin production by plant cell cultures of OnosmasericeumWilld. Braz. Arch. Biol. Technol.2016; 59: 1-7.

12. Dziri S, Hassen I, Fatnassi $S$, Mrabet $Y$, Casabianca $\mathrm{H}$, Hanchi B. Phenolicconstituents, antioxidant and antimicrobial activities of rosygarlic (Alliumroseum var. odoratissimum). J Funct Foods. 2012; 4(2): 423-32.

13. Baye $H$, Hymete $A$. Lead and cadmium accumulation in medicinal plants collected from environmentally different sites. BullEnviron Contam Toxicol. 2010; 84(2): 197-201.

14. Pytlakowska K, Kita A, Janoska P, Połowniak M, Kozik V. Multi-element analysis of mineral and trace elements in medicinal herbs and their infusions. FoodChem. 2012; 135(2): 494-501.

15. Slinkard K. Singleton VL. Total phenols analysis: Automation and comparison with manual methods.Am. J. Enol. Vitic, 1977;28: 49 -55 .

16. Kim DO, Jeong SW, Lee CY. Antioxidant capacity of phenolic phytochemicals from various cultivars of plums, Food Chem. 2003;81(3): 321 -6 .

17. Floegel A, Kim DO, Chung SJ, Koo SI, Chun OK. Comparison of ABTS/DPPH assays to measure antioxidant capacity in popular antioxidant-rich US foods. J Food Compost Anal.2011;24: 1043-8.
18. Turan I, Demir S, Aliyazıcıoğlu R, Aliyazıcıoğlu $Y$. Evaluation of antioxidant and cytotoxic properties of Primula vulgaris Leaf Extract. KSU J. Nat. Sci. 2017; 20(4): 361-7.

19. Cadirci E, Suleyman H, Aksoy H, Halici Z, Ozgen U, Koc A. Effects of Onosma armeniacum root extract on ethanol-induced oxidative stress in stomach tissue of rats. Chem Biol Interact. $2007 ; 170(1): 40-8$.

20. Binzet $R$, Akçin ÖE. The anatomical properties of two Onosma L. (Boraginaceae) species from Turkey.J Med Plant Res. 2012; 6(17): 3288-94.

21. Papageorgiou VP, Assimopoulou AN, Ballis AC. Alkannins and shikonins: a new class of wound healing agents. Curr Med Chem. 2008; 15:3248-67.

22. Wang L, Li F, Liu X, Chen B, Yu K, Wang MK. Meroterpenoids and a naphthoquinone from Arnebiaeuchroma and their cytotoxic activity. Planta Med.2015;81:320-6.

23. Naz S, Ahmad S, AjazRasool S, AsadSayeed $S$, SiddiqIR. Antibacterial activity directed isolation of compounds from Onosma hispidum. MicrobiolRes.2006;161:43-8.

24. Mazandarani $M$, Moghaddam PZ, Baiat $H$, Zolfaghari MR, Ghaemiand EA, Hemati $H$. Antioxidant activity, phenol, flavonoid and anthocyanin contents in various extracts of Onosma dichroanthum Boiss. in north of Iran Masoumeh. Iran. J. Plant Physiol. 2011; 1(3): $169-76$.

25. Kirkan B, Sarikurkcu C, Ozer MS, Cengiz M, Atılgan N,Ceylan O, Tepe B. Phenolic profile, antioxidant and enzyme inhibitory potential of Onosma tauricum var. Tauricum. Ind Crops Prod.2018; 125:549-55.

26. Bıçkıcı Ş. Bazı Alkanna türlerinin biyoaktivite rehberli izolasyon yöntemi kullanılarak çeşitli kanser hücreleri üzerindeki sitotoksik etkilerinin in vitro ortamda taranması [Master of Science Thesis].[İzmir]:Ege University;2006. 
